\title{
Cardiopulmonary Exercise Testing and Other Tests of Functional Capacity
}

\author{
Marissa Ferguson $^{1}\left[\right.$ [D $\cdot$ Mark Shulman ${ }^{1}$
}

Accepted: 27 October 2021 / Published online: 20 November 2021

(c) The Author(s), under exclusive licence to Springer Science+Business Media, LLC, part of Springer Nature 2021

\begin{abstract}
Purpose of Review Assessment of functional capacity is a cornerstone of preoperative risk assessment. While subjective clinician assessment of functional capacity is poorly predictive of postoperative outcomes, other objective functional assessment measures may provide more useful information.

Recent Findings Cardiopulmonary exercise testing (CPET) is generally accepted as the gold standard for functional capacity assessment. However, CPET is resource-intensive and not universally available. Simpler objective tests of functional capacity such as the Duke Activity Status Index (DASI) and the 6-min walk test (6MWT) are cheap and efficient. In addition, they predict important postoperative outcomes including death, disability, and myocardial infarction.

Summary Simple preoperative tests such as the DASI may be useful for routine preoperative assessment. CPET may be helpful to investigate further patients with functional status limitation, and to guide prehabilitation and perioperative shared decision-making in high-risk patients.
\end{abstract}

Keywords Perioperative medicine - Cardiopulmonary exercise testing · Risk assessment · Functional status assessment . Duke Activity Status Index · 6-min walk test

\section{Introduction}

Approximately $17 \%$ of patients worldwide suffer major postoperative complications [1]. With around 319 million operations performed each year globally, this equates to a significant global burden of disease [2, 3]. A large proportion of postoperative complications occur in the highest risk patients [4]; for example, major postoperative complications occur in $32 \%$ of patients with significant co-morbidities [1] and $20 \%$ of elderly patients [5]. Major postoperative complications predict long-term survival [6], and early intervention may prevent death after complications ("failure to rescue") [7].

Functional capacity assessment is a cornerstone of preoperative assessment. The key aims of functional status

This article is part of the Topical Collection on Prehabilitation

Marissa Ferguson

Marissa.ferguson@austin.org.au

Mark Shulman

Mark.shulman@monash.edu

1 Austin Hospital, 145 Studley Rd, Heidelberg, VIC, Australia assessment include risk stratification, assessing the response to prehabilitation or preoperative optimization, and guiding shared decision-making and postoperative destination planning, e.g., critical care admission. Of note, most outcomes studied to date are postoperative complications (predominantly cardiovascular complications) or death. However, more recently, there has been increasing recognition that patient-centered outcomes such as postoperative disabilityfree survival, and quality of life may be equally (or more) important $[8,9]$.

The American Heart Association/American College of Cardiology (AHA/ACC) and the European Society of Cardiology/European Society of Anaesthesia (ESC/ESA) guidelines on preoperative cardiovascular assessment both emphasize assessment of functional capacity early in their algorithms $[10,11]$. Cardiopulmonary exercise testing (CPET) is generally considered the gold standard for objectively quantifying functional capacity and the ability to meet the metabolic demands of major surgery, but is timeconsuming and resource-intensive [12]. Simple objective tests of functional capacity using a structured questionnaire (the Duke Activity Status Index, DASI), and shorter protocolized exercise testing (the 6-min walk test [6MWT] and 
the incremental shuttle walk test [ISWT]) may also provide valuable preoperative risk information.

\section{Search Strategy}

We performed a literature review of PubMed, Medline, and Google Scholar using keywords for the perioperative period and cardiopulmonary exercise testing, Duke Activity Status Index, functional status assessment, and perioperative outcomes (mortality, complications, days at home, and disability-free survival). The search strategy included metaanalyses, systematic reviews, and observational studies.

\section{Subjective Assessment of Functional Capacity}

The AHA/ACC and ESC/ESA algorithms for preoperative cardiac risk assessment both recommend proceeding with surgery if the patient has at least moderate functional capacity, defined as $\geq 4$ metabolic equivalents (METS) [10,11]. One MET is the oxygen uptake at rest, generally $3.5 \mathrm{~mL} /$ $\mathrm{kg} / \mathrm{min}$ [13]. Physical activities that require approximately 4 METS include gardening, calisthenics without weights, golfing without a cart, slow swimming, walking $4.5 \mathrm{mph}$, and mowing the lawn [13].

The AHA/ACC and ESC/ESA guidelines on preoperative cardiovascular assessment include the classic thresholds of climbing a hill or 1-2 flights of stairs as activities requiring $>4$ METS $[10,11]$. There is evidence that postoperative complications are inversely related to the number of (selfreported) blocks or flights of stairs that a patient can walk or climb, with an inability to walk at least four blocks and climb two flights of stairs associated with an increased risk for major postoperative complications (sensitivity $71 \%$; positive likelihood ratio of 1.3) [14]. However, a large observational study found that subjective clinician assessment has a low sensitivity for identifying patients with poor functional capacity (when correlated with the gold standard of CPET) and was not predictive of postoperative morbidity or mortality among patients undergoing major inpatient non-cardiac surgery $[15 \bullet \bullet$.

\section{Cardiopulmonary Exercise Testing}

CPET objectively evaluates the integrated function of the cardiorespiratory system and cellular respiration at the tissue level [16]. It involves baseline resting gas exchange(oxygen uptake, carbon dioxide production) analysis, followed by exercise stress testing (generally using a bicycle ergometer) continuous ECG monitoring, and breath-by-breath gas exchange analysis to peak exercise. Vital sign measurement and gas exchange analysis are also measured during the recovery phase after exercise [13]. While there are several commonalities between the stress of exercise and the perioperative stress response, such as increased heart rate and myocardial work, other critical pathophysiologic changes that may predispose to postoperative complications cannot be replicated (e.g., prothrombotic alterations in hemostasis, endothelial dysfunction, anemia, hypotension) [17-19].

Preoperative CPET for risk prediction increased in clinical use during the 1990s after several small observational studies suggested that CPET may be useful in predicting perioperative morbidity and mortality [20, 21]. Key CPET variables include the peak oxygen uptake (peak VO2) and the oxygen uptake at the anerobic threshold (AT) [22, 23].

\section{Peak Oxygen Uptake and the Anerobic Threshold}

The ability to achieve $\geq 4$ METS functional capacity emerged as a key functional status threshold in major guidelines for preoperative cardiovascular risk assessment [10, 11]. This threshold was supported by a number of small observational studies suggesting that a peak $\mathrm{VO} 2<15 \mathrm{~mL} /$ $\mathrm{kg} / \mathrm{min}$ (roughly $<4$ METS) is associated with postoperative mortality and complications after intra-abdominal, aortic, and thoracic surgery [24-28, 29••]. In general, a peak VO2 greater than $20 \mathrm{~mL} / \mathrm{kg} / \mathrm{min}$ is associated with a low risk for perioperative morbidity and mortality after non-cardiac surgery [25]. However, the association between peak VO2 and perioperative outcomes is not consistent and was only present in $45 \%$ of studies identified in a recent systematic review [29••]. Of note, the peak VO2 is effort-dependent, and factors other than exercise capacity such as patient motivation and joint pain may affect performance [23].

The anerobic threshold is the oxygen uptake at which lactate production begins to increase and reflects a shift from aerobic to anerobic (glycolytic) metabolism [22]. The AT is effort-independent, although there is greater inter-observer measurement error compared to the peak VO2 [23]. Numerous small observational studies have found an association between an AT $<9-11 \mathrm{~mL} / \mathrm{kg} / \mathrm{min}$ and postoperative complications and mortality after non-cardiac surgery [20, 27, $28,30-36]$. Studies using an AT threshold of 9-11 mL/ $\mathrm{kg} / \mathrm{min}$ have demonstrated high negative predictive values (94-100\%) for postoperative mortality, although this likely reflects the low incidence of this outcome [29••]. Similar to peak $\mathrm{VO} 2$, the association between $\mathrm{AT}$ and perioperative outcomes is not consistent and was only present in $51 \%$ of studies identified in a recent systematic review [29••].

A limitation of the CPET evidence to date has been poor study methodology [37]. All studies on preoperative CPET identified during the literature search for the 2017 Canadian Cardiovascular Society Guidelines were of "very low" 
quality [38]. Systematic reviews have identified frequent study limitations including small sample size, single-center design, heterogeneous patient populations, variable CPET methodology and outcome measurement, and high risk for

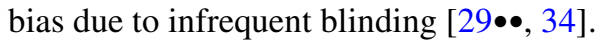

The largest and most rigorously conducted study investigating CPET for perioperative risk prediction is the measurement of exercise tolerance for surgery (METS) study. This blinded prospective multicenter cohort study compared preoperative subjective assessment, objective functional assessment (CPET, DASI), and biomarkers (NT-proBNP) for predicting death or complications after major elective non-cardiac surgery among patients with risk factors for cardiac complications $[15 \bullet \bullet]$. The primary outcome was the accuracy of CPET in predicting 30-day mortality and non-fatal MI; secondary outcomes included 12-month mortality and postoperative complications. The peak VO2 and AT were not predictive of either the primary or secondary endpoints and were also not predictive of disability-free survival in a sub-study [39•]. However, on post-hoc analysis, the peak VO2 was predictive of moderate or severe postoperative complications including surgical site infection, respiratory failure, pneumonia, critical care readmission, and reoperation.

\section{Other CPET-Derived Variables}

CPET provides a large array of other variables in addition to the peak VO2 and the AT. Markers of cardiac and pulmonary pathology on CPET may suggest organ-specific pathology and prompt further investigation. Indicators of exercise-induced myocardial ischemia on CPET include ECG changes, the duration of oxygen pulse flattening (oxygen uptake divided by heart rate), and the presence of an inflection point in the graph comparing oxygen uptake vs. work rate [40].

The prognostic significance of an abnormal stress ECG depends on the workload at which ischemic signs or symptoms develop, with greater significance given to onset at low workload [41]. Oxygen pulse flattening and an abnormal oxygen uptake vs. work rate may reflect ischemia-induced left ventricular dysfunction and the inability to increase stroke volume to meet elevated tissue oxygen delivery demands during exercise [42]. These parameters may identify exercise-induced ischemia even in the absence of ECG changes [40].

Abnormal heart rate responses to exercise may also predict adverse outcomes. Both an impaired and an exaggerated heart rate response to exercise may be suggestive of underlying cardiac pathology [23]. A delayed heart rate recovery after exercise is a surrogate for vagal dysfunction and may predict postoperative complications [43]. For example, a post-exercise heart rate reduction $\leq 12$ beats/min from peak exercise was associated with postoperative myocardial injury among 1741 patients enrolled in a planned METS sub-study [44•].

The ventilatory equivalent for carbon dioxide at anerobic threshold (VE/VCO2) represents the gas exchange capacity of the lungs, and is a surrogate for ventilation-perfusion matching and physiologic dead space [22]. A VE/ $\mathrm{VCO} 2>34-42$ is associated with postoperative mortality and complications [24, 30, 35, 45]. However, this association has not been uniformly demonstrated; only $36 \%$ of CPET studies identified in a recent systematic review found an association between $\mathrm{VE} / \mathrm{VCO} 2$ and postoperative outcomes $[29 \bullet \bullet]$.

\section{The Duke Activity Status Index}

The DASI is a structured 12-item survey assessing the ability to complete various physical tasks [46]. The DASI score ranges from 0 to 58.2 and can be used to calculate a predicted peak oxygen consumption (predicted peak $\mathrm{VO} 2=0.43 \times$ DASI +9.6$)$ [46]. There is modest correlation between the DASI score and peak VO2, and DASI has a moderate ability to predict a peak $\mathrm{VO} 2>15 \mathrm{~mL} / \mathrm{kg} / \mathrm{min}$ (AUC 0.77) [47]. A simplified modified version of the DASI (m-DASI) questionnaire using four or five questions may have similar ability to identify patients with at least moderate functional capacity [48]. A score of three using the fourquestion m-DASI questionnaire is associated with a 59\% probability of achieving an AT $>11 \mathrm{~mL} / \mathrm{kg} / \mathrm{min}$ and a $71 \%$ probability of achieving an $\mathrm{VO} 2$ peak $>16 \mathrm{~mL} / \mathrm{kg} / \mathrm{min}$ [49].

In the METS study, DASI was the only independent predictor of 30-day death or non-fatal myocardial infarction $[15 \bullet \bullet]$. Furthermore, on a sub-study, DASI was the only independent predictor of 12-month disability-free survival [39•]. A threshold DASI score of $<34$ (corresponding to a peak VO2 of $17-18 \mathrm{~mL} / \mathrm{kg} / \mathrm{min}$ ) may be used to identify patients at elevated risk for myocardial injury/infarction, moderate to severe postoperative complications, or new postoperative disability $[50 \bullet]$.

\section{Walking Tests}

The 6-min walk test (6MWT) is a sub-maximal exercise test that involves a patient walking on the flat back and forth between two distance markers. Early observational data suggested that it had good ability to discriminate between moderate $(>11 \mathrm{~mL} / \mathrm{kg} / \mathrm{min})$ and low $(<11 \mathrm{~mL} / \mathrm{kg} / \mathrm{min})$ AT in patients awaiting major non-cardiac surgery, with lower and upper distance cut-points of $<427$ and $>563 \mathrm{~m} \mathrm{[51].} \mathrm{A}$ sub-study of 574 patients enrolled in the METS study found poor correlation between the 6MWT and 30-day quality of 
recovery or 12 -month new postoperative disability [39•]. However, comparing the lowest tertile $(<435 \mathrm{~m})$ versus the highest tertile $(>510 \mathrm{~m})$ predicted new disability and 12-month disability-free survival on post-hoc analysis, and a 6 MWT $<350 \mathrm{~m}$ had $90 \%$ sensitivity and $73 \%$ specificity for predicting 12-month disability [39•]. For these outcome measures, the 6MWT was equivalent or superior to CPET.

The incremental shuttle walk test (ISWT) involves walking on the flat between two points at increasing speed [52]. In contrast to the $6 \mathrm{MWT}$, the increasing pace during the ISWT simulates peak functional capacity testing using a ramp protocol. The ISWT has moderate to good correlation with the peak VO2 measured using CPET [47, 52], and threshold of $>360 \mathrm{~m}$ has a high positive predictive value for a peak $\mathrm{VO} 2>15 \mathrm{~mL} / \mathrm{kg} / \mathrm{min}$ and an $\mathrm{AT}>11 \mathrm{~mL} / \mathrm{kg} / \mathrm{min}$ on CPET based on the results of one small observational study [47] (Table 1). However, the utility of the ISWT has not been evaluated in large prospective studies in the perioperative period.

\section{Functional Status Assessment in Practice}

The DASI is a cheap and simple objective test of functional capacity, and is more accurate at predicting postoperative outcomes that subjective clinician assessment. Preoperative CPET may be useful in select patients, particularly those identified as high-risk using the DASI questionnaire. CPET is more useful for predicting major postoperative complications compared to cardiac risk prediction. There is a margin of error in all CPET parameters, and a single cut-off to discriminate between high versus low risk may be overly simplistic [54]. No single CPET variable has uniformly been found to predict postoperative outcomes [29••], and the utility of different CPET variables may differ depending upon the type of surgery and underlying patient comorbidities [37].

Further research is required to determine whether the integration of CPET into preoperative assessment and management protocols improves postoperative outcomes. Several small observational studies have suggested that preoperative exercise training ("prehabilitation") can improve CPET markers of functional capacity [55, 56], although it is unclear whether this translates into improved postoperative outcomes [57, 58]. Prehabilitation may be particularly important for patients undergoing cancer surgery to attenuate the reduction in functional capacity associated with neoadjuvant chemoradiotherapy [57]. Several multicenter randomized controlled trials are currently in progress investigating whether CPET-guided prehabilitation can reduce major postoperative complications [59-62]. Recently published consensus guidelines will aid in improving the quality of these future perioperative CPET studies [63].

Aside from accuracy, other pragmatic factors such as cost, complexity, availability, time, and expertise requirement are important determinants of the utility of a functional status assessment tool. While CPET is available in $53 \%$ of UK trusts [64], availability in other areas of the world is likely to be lower, particular in low and middle-income countries. Furthermore, CPET is problematic in the era of the coronavirus pandemic due to safety concerns for viral transmission and resource limitations due to pressures placed on health systems in caring for infected patients [65].

Preoperative biomarkers such as brain natriuretic peptide (BNP) and troponin are simple, quick, and relatively cheap options for preoperative risk assessment that may complement functional status assessment. The preoperative BNP and N-terminal pro-Brain Natriuretic Peptide (NT-pro BNP)

Table 1 Cut-points that help triage patients at increased risk for postoperative complications

\begin{tabular}{|c|c|c|c|c|c|}
\hline Test & $\mathrm{AT}<11 \mathrm{~mL} / \mathrm{kg} / \mathrm{min}$ & $\mathrm{AT}>11 \mathrm{~mL} / \mathrm{kg} / \mathrm{min}$ & $\begin{array}{l}\mathrm{pVO} 2<15 \mathrm{~mL} / \\
\mathrm{kg} / \mathrm{min}\end{array}$ & $\mathrm{pVO} 2>15 \mathrm{~mL} / \mathrm{kg} / \mathrm{min}$ & Outcome \\
\hline DASI & & & & $>34[15 \bullet \bullet, 50 \bullet]$ & $\begin{array}{l}<34 \text { : increased risk for } 30 \text {-day } \\
\text { death or postoperative myocardial } \\
\text { infarction and moderate-to-severe } \\
\text { complications }[50 \bullet]\end{array}$ \\
\hline m-DASI & & $\begin{array}{l}66 \% \text { probability } \\
\text { with } 4 / 4 \text { questions } \\
\text { [49] }\end{array}$ & & $\begin{array}{l}84 \% \text { probability with } \\
4 / 4 \text { questions [49] }\end{array}$ & \\
\hline $6 \mathrm{MWT}$ & $<427 \mathrm{~m}[51]$ & $>563 \mathrm{~m}[51]$ & & & $\begin{array}{l}<350 \mathrm{~m}: 20 \% \text { chance of significant } \\
\text { increase in } 12 \text {-month disability } \\
{[39 \bullet]}\end{array}$ \\
\hline ISWT & & $>360 \mathrm{~m}$ [47] & & $>360 \mathrm{~m}$ [47] & \\
\hline Natriuretic peptides & & & & & $\begin{array}{l}\text { NT-pro BNP }>92 \mathrm{ng} / \mathrm{L} \text { or } \\
\text { BNP }>300 \text { ng/L: increased post- } \\
\text { operative death or MI at } 30 \text { days } \\
\text { and } \geq 180 \text { days }[53]\end{array}$ \\
\hline
\end{tabular}


level both independently predict mortality and cardiac complications after major non-cardiac surgery [53, 66-69] and cardiac surgery [70, 71]. In the METS study, preoperative NT-proBNP was predictive of 12-month mortality and death or myocardial injury within 30 days postoperatively [15••]. Similar to BNP, preoperative troponin levels are associated with postoperative cardiac complications [72-75]. Preoperative natriuretic peptide measurement improves the net risk reclassification in $32 \%$ of patients for postoperative mortality or non-fatal MI in addition to baseline clinical variables alone (age, revised cardiac risk index [RCRI], type of surgery, urgency of surgery; net reclassification improvement 32\%) [53]. Another advantage of natriuretic peptides over troponins is that risk thresholds have been identified; BNP levels $\geq 92 \mathrm{ng} / \mathrm{L}$ or NT-proBNP levels $\geq 300 \mathrm{ng} / \mathrm{L}$ are strong independent predictors of postoperative death or MI at 30 days and $\geq 180$ days [53]. As a result, the Canadian Cardiac Society guidelines recommend preoperative natriuretic peptide measurement for patients with a $>5 \%$ predicted risk of 30-day postoperative cardiovascular death or non-fatal myocardial infarction (age $\geq 65$, age 45-64 and significant cardiovascular disease, or RCRI score $\geq 1$ ) [38]. Early postoperative BNP and troponin levels may be even more predictive of postoperative morbidity and mortality than preoperative levels $[53,76]$. However, routine clinical use of perioperative biomarker measurement is currently limited by the lack of established postoperative management algorithms demonstrating improved outcomes based on these variables [75].

\section{Conclusions}

Functional status assessment is a key component of preoperative risk assessment, although there is not one single parameter or cut-point that reliably discriminates patients at "high-risk" of postoperative complications and/or death. The Duke Activity Status Index is a cheap, simple and objective starting point for functional status assessment, and a DASI score of $>34$ has been proposed to replace subjective assessment of reduced functional capacity [77]. Among patients identified as high-risk using the DASI questionnaire, further functional capacity testing such as 6MWT, ISWT and escalation to CPET, with consideration for biomarkers (troponin, BNP) may be useful to guide risk stratification, referral for prehabilitation (CPET), and postoperative destination planning (e.g., ICU).

\section{Declarations}

Conflict of interest The authors do not have any potential conflicts of interest to disclose.

\section{References}

Papers of particular interest, published recently, have been highlighted as:

- Of importance

$\bullet$ Of major importance

1. International Surgical Outcomes Study group. Global patient outcomes after elective surgery: prospective cohort study in 27 low-, middle- and high-income countries. Br J Anaesth. 2016;117(5):601-9. https://doi.org/10.1093/bja/aew316.

2. Weiser TG, Haynes AB, Molina G, Lipsitz SR, Esquivel MM, Uribe-Leitz T, et al. Estimate of the global volume of surgery in 2012: an assessment supporting improved health outcomes. Lancet. 2015;385(Suppl 2):S11. https://doi.org/10.1016/s01406736(15)60806-6.

3. Bainbridge D, Martin J, Arango M, Cheng D. Perioperative and anaesthetic-related mortality in developed and developing countries: a systematic review and meta-analysis. Lancet. 2012;380(9847):1075-81. https://doi.org/10.1016/s01406736(12)60990-8.

4. Pearse RM, Harrison DA, James P, Watson D, Hinds C, Rhodes A, et al. Identification and characterisation of the highrisk surgical population in the United Kingdom. Crit Care. 2006;10(3):R81. https://doi.org/10.1186/cc4928.

5. Story DA, Leslie K, Myles PS, Fink M, Poustie SJ, Forbes A, et al. Complications and mortality in older surgical patients in Australia and New Zealand (the REASON study): a multicentre, prospective, observational study. Anaesthesia. 2010;65(10):1022-30. https://doi.org/10.1111/j.1365-2044. 2010.06478.x.

6. Khuri SF, Henderson WG, DePalma RG, Mosca C, Healey NA, Kumbhani DJ. Determinants of long-term survival after major surgery and the adverse effect of postoperative complications. Ann Surg. 2005;242(3):326-41; discussion 41-3. 00000658200509000-00004 [pii].

7. Ghaferi AA, Birkmeyer JD, Dimick JB. Variation in hospital mortality associated with inpatient surgery. N Engl J Med. 2009;361(14):1368-75. https://doi.org/10.1056/NEJMsa0903 048.

8. Shulman MA, Myles PS, Chan MT, McIlroy DR, Wallace S, Ponsford J. Measurement of disability-free survival after surgery. Anesthesiology. 2015;122(3):524-36. https://doi.org/10.1097/ aln.0000000000000586.

9. Moonesinghe SR, Jackson AIR, Boney O, Stevenson N, Chan MTV, Cook TM, et al. Systematic review and consensus definitions for the standardised endpoints in perioperative medicine initiative: patient-centred outcomes. Br J Anaesth. 2019;123(5):664-70. https://doi.org/10.1016/j.bja.2019.07.020.

10. Kristensen SD, Knuuti J, Saraste A, Anker S, Botker HE, De Hert S, et al. 2014 ESC/ESA Guidelines on non-cardiac surgery: cardiovascular assessment and management: The Joint Task Force on non-cardiac surgery: cardiovascular assessment and management of the European Society of Cardiology (ESC) and the European Society of Anaesthesiology (ESA). Eur Heart J. 2014;14(35):2383-431. https://doi.org/10.1093/eurheartj/ ehu282.

11. Fleisher LA, Fleischmann KE, Auerbach AD, Barnason SA, Beckman JA, Bozkurt B, et al. 2014 ACC/AHA guideline on perioperative cardiovascular evaluation and management of patients undergoing noncardiac surgery: a report of the American College of Cardiology/American Heart Association Task Force on practice guidelines. Circulation. 2014;130(24):e278333. https://doi.org/10.1161/cir.0000000000000106. 
12. Wasserman K, Hansen JE, Sue DY, Stringer WW, Whipp BJ. Principles of exercise testing and interpretation. 4th ed. Philadelphia: Lippincott Williams \& Wilkins; 2004.

13. Fletcher GF, Balady GJ, Amsterdam EA, Chaitman B, Eckel $\mathrm{R}$, Fleg $\mathrm{J}$, et al. Exercise standards for testing and training: a statement for healthcare professionals from the American Heart Association. Circulation. 2001;104(14):1694-740.

14. Reilly DF, McNeely MJ, Doerner D, Greenberg DL, Staiger TO, Geist MJ, et al. Self-reported exercise tolerance and the risk of serious perioperative complications. Arch Intern Med. 1999;159(18):2185-92. https://doi.org/10.1001/archinte.159.18. 2185.

15.• Wijeysundera DN, Pearse RM, Shulman MA, Abbott TEF, Torres E, Ambosta A, et al. Assessment of functional capacity before major non-cardiac surgery: an international, prospective cohort study. Lancet. 2018;391(10140):2631-40. https://doi. org/10.1016/s0140-6736(18)31131-0. (The Measurement of Exercise Tolerance for Surgery (METS) study is the largest blinded prospective multicentre cohort study to compare preoperative subjective assessment, objective functional assessment (CPET, DASI) and biomarkers (NT-proBNP) for predicting death or complications after major elective non-cardiac surgery)

16. Guazzi M, Bandera F, Ozemek C, Systrom D, Arena R. Cardiopulmonary exercise testing: what is its value? J Am Coll Cardiol. 2017;70(13):1618-36. https://doi.org/10.1016/j.jacc.2017.08. 012.

17. Priebe HJ. Perioperative myocardial infarction-aetiology and prevention. Br J Anaesth. 2005;95(1):3-19. https://doi.org/10. 1093/bja/aei063.

18. Devereaux PJ, Goldman L, Cook DJ, Gilbert K, Leslie K, Guyatt G. Perioperative cardiac events in patients undergoing noncardiac surgery: a review of the magnitude of the problem, the pathophysiology of events and methods to estimate and communicate risk. CMAJ. 2005;173(6):627-34.

19. Alpert JS, Thygesen KA, White HD, Jaffe AS. Diagnostic and therapeutic implications of type 2 myocardial infarction: review and commentary. Am J Med. 2014;127(2):105-8. https://doi.org/ 10.1016/j.amjmed.2013.09.031.

20. Older P, Smith R, Courtney P, Hone R. Preoperative evaluation of cardiac failure and ischemia in elderly patients by cardiopulmonary exercise testing. Chest. 1993;104(3):701-4. https://doi. org/10.1378/chest.104.3.701.

21. Older P, Hall A, Hader R. Cardiopulmonary exercise testing as a screening test for perioperative management of major surgery in the elderly. Chest. 1999;116(2):355-62.

22. Older PO, Levett DZH. Cardiopulmonary exercise testing and surgery. Ann Am Thorac Soc. 2017;14(Supplement_1):S74-S83. https://doi.org/10.1513/AnnalsATS.201610-780FR.

23. Otto J, Levett D, Grocott M. Cardiopulmonary exercise testing for preoperative evaluation: what does the future hold? Curr Anesthesiol Rep. 2020;10:1-11.

24. Grant SW, Hickey GL, Wisely NA, Carlson ED, Hartley RA, Pichel AC, et al. Cardiopulmonary exercise testing and survival after elective abdominal aortic aneurysm repair $\dagger$. Br J Anaesth. 2015;114(3):430-6. https://doi.org/10.1093/bja/aeu383.

25. Beckles MA, Spiro SG, Colice GL, Rudd RM. The physiologic evaluation of patients with lung cancer being considered for resectional surgery. Chest. 2003;123(1 Suppl):105s-s114. https:// doi.org/10.1378/chest.123.1_suppl.105s.

26. McCullough PA, Gallagher MJ, Dejong AT, Sandberg KR, Trivax JE, Alexander D, et al. Cardiorespiratory fitness and short-term complications after bariatric surgery. Chest. 2006;130(2):517-25. https://doi.org/10.1378/chest.130.2.517.

27. West MA, Lythgoe D, Barben CP, Noble L, Kemp GJ, Jack S, et al. Cardiopulmonary exercise variables are associated with postoperative morbidity after major colonic surgery: a prospective blinded observational study. Br J Anaesth. 2014;112(4):66571. https://doi.org/10.1093/bja/aet408.

28. Hartley RA, Pichel AC, Grant SW, Hickey GL, Lancaster PS, Wisely NA, et al. Preoperative cardiopulmonary exercise testing and risk of early mortality following abdominal aortic aneurysm repair. Br J Surg. 2012;99(11):1539-46. https://doi.org/10.1002/ bjs.8896.

$29 . \bullet$ Stubbs DJ, Grimes LA, Ercole A. Performance of cardiopulmonary exercise testing for the prediction of post-operative complications in non cardiopulmonary surgery: a systematic review. PLoS ONE. 2020;15(2):e0226480. https://doi.org/10.1371/journ al.pone.0226480. (This is the most recent systematic review published on the utlity of preoperative CPET for predicting postoperative complications after noncardiac surgery)

30. Wilson RJ, Davies S, Yates D, Redman J, Stone M. Impaired functional capacity is associated with all-cause mortality after major elective intra-abdominal surgery. Br J Anaesth. 2010;105(3):297-303. https://doi.org/10.1093/bja/aeq128.

31. Older P, Hall A. Clinical review: how to identify high-risk surgical patients. Crit Care. 2004;8(5):369-72. https://doi.org/10. 1186/cc2848.

32. Smith TB, Stonell C, Purkayastha S, Paraskevas P. Cardiopulmonary exercise testing as a risk assessment method in non cardio-pulmonary surgery: a systematic review. Anaesthesia. 2009;64(8):883-93. https://doi.org/10.1111/j.1365-2044.2009. 05983.x.

33. Snowden CP, Prentis JM, Anderson HL, Roberts DR, Randles D, Renton M, et al. Submaximal cardiopulmonary exercise testing predicts complications and hospital length of stay in patients undergoing major elective surgery. Ann Surg. 2010;251(3):53541. https://doi.org/10.1097/SLA.0b013e3181cf811d.

34. Moran J, Wilson F, Guinan E, McCormick P, Hussey J, Moriarty $\mathrm{J}$. Role of cardiopulmonary exercise testing as a risk-assessment method in patients undergoing intra-abdominal surgery: a systematic review. Br J Anaesth. 2016;116(2):177-91. https://doi. org/10.1093/bja/aev454.

35. Junejo MA, Mason JM, Sheen AJ, Moore J, Foster P, Atkinson D, et al. Cardiopulmonary exercise testing for preoperative risk assessment before hepatic resection. Br J Surg. 2012;99(8):1097-104. https://doi.org/10.1002/bjs.8773.

36. Prentis JM, Trenell MI, Jones DJ, Lees T, Clarke M, Snowden CP. Submaximal exercise testing predicts perioperative hospitalization after aortic aneurysm repair. J Vasc Surg. 2012;56(6):1564-70. https://doi.org/10.1016/j.jvs.2012.05.097.

37. Biccard BM. Improving the evidence-base for preoperative cardiopulmonary exercise testing. Br J Anaesth. 2018;120(3):419 21. https://doi.org/10.1016/j.bja.2017.12.007.

38. Duceppe E, Parlow J, MacDonald P, Lyons K, McMullen M, Srinathan S, et al. Canadian Cardiovascular Society Guidelines on Perioperative Cardiac Risk Assessment and Management for Patients Who Undergo Noncardiac Surgery. Can J Cardiol. 2017;33(1):17-32. https://doi.org/10.1016/j.cjca.2016.09.008.

39. Shulman MA, Cuthbertson BH, Wijeysundera DN, Pearse RM, Thompson B, Torres E, et al. Using the 6-minute walk test to predict disability-free survival after major surgery. (1471-6771 (Electronic)). This prespecified sub-study of the Measurement of Exercise Tolerance for Surgery study assessed the utility of the 6MWT in predicting important patient-centered outcomes after major noncardiac surgery

40. Belardinelli R, Lacalaprice F, Carle F, Minnucci A, Cianci G, Perna G, et al. Exercise-induced myocardial ischaemia detected by cardiopulmonary exercise testing. Eur Heart J. 2003;24(14):1304-13.

41. Fleisher LA, Beckman JA, Brown KA, Calkins H, Chaikof EL, Fleischmann KE, et al. 2009 ACCF/AHA focused update on 
perioperative beta blockade incorporated into the ACC/AHA 2007 guidelines on perioperative cardiovascular evaluation and care for noncardiac surgery : a report of the American College of Cardiology Foundation/American Heart Association Task Force on Practice Guidelines. Circulation. 2009;120(21):e169-276.

42. Chaudhry S, Arena R, Wasserman K, Hansen JE, Lewis GD, Myers J, et al. Exercise-induced myocardial ischemia detected by cardiopulmonary exercise testing. Am J Cardiol. 2009;103(5):615-9. https://doi.org/10.1016/j.amjcard.2008.10. 034.

43. Ackland GL, Abbott TEF, Minto G, Clark M, Owen T, Prabhu $\mathrm{P}$, et al. Heart rate recovery and morbidity after noncardiac surgery: Planned secondary analysis of two prospective, multi-centre, blinded observational studies. PLoS ONE. 2019;14(8):e0221277. https://doi.org/10.1371/journal.pone. 0221277.

44.• Abbott TEF, Pearse RM, Cuthbertson BH, Wijeysundera DN, Ackland GL. Cardiac vagal dysfunction and myocardial injury after non-cardiac surgery: a planned secondary analysis of the measurement of Exercise Tolerance before surgery study. $\mathrm{Br}$ J Anaesth. 2019;122(2):188-97. https://doi.org/10.1016/j.bja. 2018.10.060. (This sub-study of the Measurement of Exercise Tolerance for Surgery (METS) study assessed the importance of heart rate recovery - a surrogate for cardiac vagal dysunction - in predicting postoperative myocardial injury after major noncardiac surgery)

45. Carlisle J, Swart M. Mid-term survival after abdominal aortic aneurysm surgery predicted by cardiopulmonary exercise testing. Br J Surg. 2007;94(8):966-9. https://doi.org/10.1002/bjs. 5734.

46. Hlatky MA, Boineau RE, Higginbotham MB, Lee KL, Mark $\mathrm{DB}$, Califf RM, et al. A brief self-administered questionnaire to determine functional capacity (the Duke Activity Status Index). Am J Cardiol. 1989;64(10):651-4.

47. Struthers R, Erasmus P, Holmes K, Warman P, Collingwood A, Sneyd JR. Assessing fitness for surgery: a comparison of questionnaire, incremental shuttle walk, and cardiopulmonary exercise testing in general surgical patients. Br J Anaesth. 2008;101(6):774-80. https://doi.org/10.1093/bja/aen310.

48. Riedel B, Li MH, Lee CHA, Ismail H, Cuthbertson BH, Wijeysundera DN, et al. A simplified (modified) Duke Activity Status Index (M-DASI) to characterise functional capacity: a secondary analysis of the Measurement of Exercise Tolerance before Surgery (METS) study. Br J Anaesth. 2021;126(1):181-90. https:// doi.org/10.1016/j.bja.2020.06.016.

49. Lee CHA, Ismail H, Ho KM, Riedel B, Schier R. Thresholds of functional capacity using the four-question (modified) Duke Activity Status Index (M-DASI-4Q) as a screening tool: observations from the measurement of exercise tolerance before surgery (METS) study. Br J Anaesth. 2021;126(3):e92-4. https://doi.org/ 10.1016/j.bja.2020.11.023.

50. Wijeysundera DN, Beattie WS, Hillis GS, Abbott TEF, Shulman MA, Ackland GL, et al. Integration of the Duke Activity Status Index into preoperative risk evaluation: a multicentre prospective cohort study. Br J Anaesth. 2020;124(3):261-70. https:// doi.org/10.1016/j.bja.2019.11.025. (This secondary analysis of data from the Measurement of Exercise Tolerance for Surgery (METS) study identified a threshold DASI score of 34 to predict patients at risk for postoperative death, disability and complications)

51. Sinclair RC, Batterham AM, Davies S, Cawthorn L, Danjoux GR. Validity of the $6 \mathrm{~min}$ walk test in prediction of the anaerobic threshold before major non-cardiac surgery. Br J Anaesth. 2012;108(1):30-5. https://doi.org/10.1093/bja/aer322.

52. Singh SJ, Morgan MD, Hardman AE, Rowe C, Bardsley PA. Comparison of oxygen uptake during a conventional treadmill test and the shuttle walking test in chronic airflow limitation. Eur Respir J. 1994;7(11):2016-20.

53. Rodseth RN, Biccard BM, Le Manach Y, Sessler DI, Lurati Buse $\mathrm{GA}$, Thabane $\mathrm{L}$, et al. The prognostic value of pre-operative and post-operative B-type natriuretic peptides in patients undergoing noncardiac surgery: B-type natriuretic peptide and $\mathrm{N}$-terminal fragment of pro-B-type natriuretic peptide: a systematic review and individual patient data meta-analysis. J Am Coll Cardiol. 2014;63(2):170-80. https://doi.org/10.1016/j.jacc.2013.08.1630.

54. Rose GA, Davies RG, Davison GW, Adams RA, Williams IM, Lewis MH, et al. The cardiopulmonary exercise test grey zone; optimising fitness stratification by application of critical difference. Br J Anaesth. 2018;120(6):1187-94. https://doi.org/10. 1016/j.bja.2018.02.062.

55. Minnella EM, Awasthi R, Loiselle SE, Agnihotram RV, Ferri LE, Carli F. Effect of exercise and nutrition prehabilitation on functional capacity in esophagogastric cancer surgery: a randomized clinical trial. JAMA Surg. 2018. https://doi.org/10.1001/jamas urg.2018.1645.

56. Minnella EM, Bousquet-Dion G, Awasthi R, Scheede-Bergdahl C, Carli F. Multimodal prehabilitation improves functional capacity before and after colorectal surgery for cancer: a fiveyear research experience. (1651-226X (Electronic)).

57. Richardson K, Levett DZH, Jack S, Grocott MPW. Fit for surgery? Perspectives on preoperative exercise testing and training. Br J Anaesth. 2017;119(suppl_1):i34-i43. https://doi.org/ 10.1093/bja/aex393.

58. Thomas G, Tahir MR, C. BB, Kallen VL, Slooter GD, van Meeteren NL. Prehabilitation before major intra-abdominal cancer surgery: a systematic review of randomised controlled trials. Eur J Anaesthesiol. 2019;36(933-945).

59. McIsaac DI, Saunders C, Hladkowicz E, Bryson GL, Forster AJ, Gagne S, et al. PREHAB study: a protocol for a prospective randomised clinical trial of exercise therapy for people living with frailty having cancer surgery. BMJ Open. 2018;8(6):e022057. https://doi.org/10.1136/bmjopen-2018-022057.

60. Abdullah HR, Lien VP, Ong HK, Er PL, Hao Y, Khan SA, et al. Protocol for a single-centre, randomised controlled study of a preoperative rehabilitation bundle in the frail and elderly undergoing abdominal surgery. BMJ Open. 2017;7(8):e016815. https://doi.org/10.1136/bmjopen-2017-016815.

61. The Wessex fit-4-cancer surgery trial (WesFit): NCT03509428. https://clinicaltrials.gov/ct2/show/NCT03509428 (2018). Accessed 12th Jan 2021.

62. van Rooijen SA-Ohoo, Carli F, Dalton S, Thomas G, Bojesen R, Le Guen M, et al. Multimodal prehabilitation in colorectal cancer patients to improve functional capacity and reduce postoperative complications: the first international randomized controlled trial for multimodal prehabilitation. (1471-2407 (Electronic)).

63. Levett DZH, Jack S, Swart M, Carlisle J, Wilson J, Snowden $\mathrm{C}$, et al. Perioperative cardiopulmonary exercise testing (CPET): consensus clinical guidelines on indications, organization, conduct, and physiological interpretation. Br J Anaesth. 2018;120(3):484-500. https://doi.org/10.1016/j.bja.2017.10.020.

64. Reeves T, Bates S, Sharp T, Richardson K, Bali S, Plumb J, et al. Cardiopulmonary exercise testing (CPET) in the United Kingdom-a national survey of the structure, conduct, interpretation and funding. Perioper Med (Lond). 2018;7:2. https://doi. org/10.1186/s13741-017-0082-3.

65. Faghy MA, Sylvester KP, Cooper BG, Hull JH. Cardiopulmonary exercise testing in the COVID-19 endemic phase. Br J Anaesth. 2020;125(4):447-9. https://doi.org/10.1016/j.bja.2020. 06.006 .

66. Leibowitz D, Planer D, Rott D, Elitzur Y, Chajek-Shaul T, Weiss AT. Brain natriuretic peptide levels predict perioperative events in cardiac patients undergoing noncardiac surgery: a prospective 
study. Cardiology. 2008;110(4):266-70. https://doi.org/10.1159/ 000112411.

67. Cuthbertson BH, Amiri AR, Croal BL, Rajagopalan S, Alozairi $\mathrm{O}$, Brittenden J, et al. Utility of B-type natriuretic peptide in predicting perioperative cardiac events in patients undergoing major non-cardiac surgery. Br J Anaesth. 2007;99(2):170-6. https://doi.org/10.1093/bja/aem158.

68. Cuthbertson BH, Card G, Croal BL, McNeilly J, Hillis GS. The utility of B-type natriuretic peptide in predicting postoperative cardiac events and mortality in patients undergoing major emergency non-cardiac surgery. Anaesthesia. 2007;62(9):875-81. https://doi.org/10.1111/j.1365-2044.2007.05146.x.

69. Karthikeyan G, Moncur RA, Levine O, Heels-Ansdell D, Chan MT, Alonso-Coello P, et al. Is a pre-operative brain natriuretic peptide or N-terminal pro-B-type natriuretic peptide measurement an independent predictor of adverse cardiovascular outcomes within 30 days of noncardiac surgery? A systematic review and meta-analysis of observational studies. J Am Coll Cardiol. 2009;54(17):1599-606. https://doi.org/10.1016/j.jacc. 2009.06.028.

70. Pedrazzini GB, Masson S, Latini R, Klersy C, Rossi MG, Pasotti $\mathrm{E}$, et al. Comparison of brain natriuretic peptide plasma levels versus logistic EuroSCORE in predicting in-hospital and late postoperative mortality in patients undergoing aortic valve replacement for symptomatic aortic stenosis. Am J Cardiol. 2008;102(6):749-54. https://doi.org/10.1016/j.amjcard.2008. 04.055 .

71. Akazawa $\mathrm{T}$, Nishihara $\mathrm{H}$, Iwata $\mathrm{H}$, Warabi $\mathrm{K}$, Ohshima $\mathrm{M}$, Inada E. Preoperative plasma brain natriuretic peptide level is an independent predictor of postoperative atrial fibrillation following off-pump coronary artery bypass surgery. J Anesth. 2008;22(4):347-53. https://doi.org/10.1007/s00540-008-0647-x.
72. Weber M, Luchner A, Manfred S, Mueller C, Liebetrau C, Schlitt $\mathrm{A}$, et al. Incremental value of high sensitive troponin $\mathrm{T}$ in addition to the revised cardiac index for peri-operative risk stratification in non-cardiac surgery. Eur Heart J. 2013;34(11):853-62.

73. Nagele P, Brown F, Gage BF, Gibson DW, Miller JP, Jaffe AS, et al. High-sensitivity cardiac troponin $\mathrm{T}$ in prediction and diagnosis of myocardial infarction and long-term mortality after noncardiac surgery. Am Heart J. 2013;166(2):325-32.e1. https://doi. org/10.1016/j.ahj.2013.04.018.

74. Ruetzler K, Khanna AK, Sessler DI. Myocardial injury after noncardiac surgery: preoperative, intraoperative, and postoperative aspects, implications, and directions. Anesth Analg. 2020;131(1):173-86. https://doi.org/10.1213/ane.0000000000 004567.

75. De Hert SG, Lurati Buse GA. Cardiac biomarkers for the prediction and detection of adverse cardiac events after noncardiac surgery: a narrative review. Anesth Analg. 2020;131(1):187-95. https://doi.org/10.1213/ane.0000000000004711.

76. Devereaux PJ, Chan MT, Alonso-Coello P, Walsh M, Berwanger $\mathrm{O}$, Villar JC, et al. Association between postoperative troponin levels and 30-day mortality among patients undergoing noncardiac surgery. JAMA. 2012;307(21):2295-304. https://doi.org/ 10.1001/jama.2012.5502.

77. Fleisher LA. Preoperative evaluation in 2020: does exercise capacity fit into decision-making? $\mathrm{Br} \mathrm{J}$ Anaesth. 2020;125(3):224-6. https://doi.org/10.1016/j.bja.2020.05.053.

Publisher's Note Springer Nature remains neutral with regard to jurisdictional claims in published maps and institutional affiliations. 